\title{
Remediation of Fresh Water Fishes against Bacterial Diseases: Novel In-Silico approaches
}

\author{
Shreya Srivastava, Anshul Tiwari and Prachi Srivastava* \\ Amity Institute of Biotechnology, Amity University, India
}

Submission: December 12, 2016; Published: February 27, 2017

"Corresponding author: Prachi Srivastava, Amity Institute of Biotechnology, Amity University, Lucknow, UP, India, Tel: 9453141916; Email: p.srivastava2@gmail.com

\begin{abstract}
Background: In-silico characterization and 3-D structure prediction along with comparative docking studies of herbal versus synthetic ligands against Chondroitin AC Lyase of the pathogen Flavobacterium columnare of Columnaris disease of Rohu is carried out.

Purpose: The current study has been carried out for screening of potential herbal ligand against Columnaris disease of Labeo Rohita.

Method: In-silico characterization was done by using ProtParam, NetPhos 2.0, SignalP 4.1 and SOPMA. 3-D structure of Chondroitin AC Lyase was modelled by using Modeller and the predicted 3-D structures were validated by using Procheck. Comparative docking studies for studying protein-ligand interaction were performed by using Autodock.

Results: In-silico characterization and 3-D structure was obtained along with its putative functional sites. Analysis reveals that Chondroitin AC Lyase interact with herbal ligand (Nimbolide) resulting into significant docking score and also forms H-bonds along with several hydrophobic interactions between active site residues of Chondroitin AC Lyase with respect to synthetic molecules.

Conclusion: In-silico characterization and 3-D structure prediction along with comparative docking studies reveals that Nimbolide can be used as a better herbal ligand in prophylactic measures or as a drug against Columnaris disease of Rohu by targeting Chondroitin AC Lyase enzyme of the pathogen flavobacterium columnare.
\end{abstract}

\section{Introduction}

Protein sequence analysis and characterization is one of the major challenges in front of bioinformatics as protein sequence repositories are increasing exponentially. Protein analysis in terms of characterization as well as target identification for docking studies is important application of Bioinformatics. Columnaris is the one of the major threat for fresh water fishes in current time hence there is a great demand to be focused on this disorder. Further this Columnaris disease is also much important for research orientations. 'Columnaris' disease, caused by the bacterial pathogen Flexibacter columnaris [1], is a most common disease of freshwater fishes and has a worldwide distribution. 'Columnaris' disease has been described in many freshwater fishes [2], and can be of economical importance in intensive fish farming and aquaculture [3]. Low virulence bacterial strains become pathogenic for Carps at water temperatures exceeding $20^{\circ} \mathrm{C}$, while high virulence strains may be pathogenic at temperatures above $15{ }^{\circ} \mathrm{C}$. Mortality rates ranges from $10 \%$ to $100 \%$ depending on water temperature [4].
The clinical signs and lesions are usually restricted to the surface of the body and take the form of skin erosions and gill necrosis. Characteristic 'saddleback' lesions can be found in advanced cases in major carps. A systemic infection may occur in severe cases, depending on the virulence of the strains (high and low degree virulence) [3,5]. Chondroitinase (Chondroitin AC Lyase) is one of the virulence factors that may enhance the invasiveness of the pathogen. Chondroitin AC Lyase functions by degrading chondroitin-containing structural components (i.e. cartilage) of the host tissues. The cslA gene encodes Chondroitin AC lyase. Chondroitinases are extracellular enzymes that hydrolyze chondroitin, the molecule responsible for the rigidity of the connective tissues. It has been hypothesized that dissolution of chondroitin from connective tissues allows for easier dissemination of the organism throughout its host [6 ].

In current course of study there is an attempt to characterize Chondroitin protein and prediction of structure for exploring out the physical and chemical properties by using bio computational 
tools along with the docking studies. Characterization study conclude about the physical properties of Chondroitin AC Lyase along with secondary structure further comparative 3-D structure prediction and docking studies reveals that Nimbolide can be used as a better natural ligand in prophylactic measures or as a drug against Columnaris disease by targeting Chondroitin AC Lyase protein.

\section{Materials and Methods}

\section{Protein sequence identification}

Protein sequences of Chondroitin AC Lyase was retrieved from the manually curated public protein database UniProt through the accession number G8X8L6 [7]. The sequences were retrieved in FASTA format and are further used for primary and secondary level structural analysis.

Table 1: Physico - chemical parameters of Chondroitin AC Lyase computed by Protparam.

\begin{tabular}{|c|c|c|c|c|c|c|c|c|c|}
\hline $\begin{array}{c}\text { Accession } \\
\text { number }\end{array}$ & M.wt & M.wt & pI & -R & +R & EC & II & AI & GRAVY \\
\hline G8X8L6 & 761 & 86001.3 & 8.55 & 74 & 79 & 108655 & 31.46 & 72.42 & -0.535 \\
& & & & & & & & & \\
\hline
\end{tabular}

\section{Tools and servers}

The amino acid composition of corresponding protein sequences were calculated using the tool ProtParam from ExPasy (Expert protein analysis system) [8]. Percentages of hydrophobic and hydrophilic residues were manually calculated from the primary structure analysis results. The physico-chemical parameters i.e. theoretical isoelectric point (pI), molecular weight, total number of positive and negative residues, extinction coefficient, half life, instability index, aliphatic index and grand average hydrophathy (GRAVY) were computed using the Expasy's ProtParam prediction server. Secondary structure prediction was done by using SOPMA server [9]. The NetPhos-2.0, server was used for studying potential

Table 2: Amino acid composition of Chondroitin AC Lyase.

\begin{tabular}{|c|c|}
\hline Amino Acids & G8X8L6 \\
\hline Ala & 46 \\
\hline Arg & 22 \\
\hline Asn & 86 \\
\hline Asp & 39 \\
\hline Cys & 2 \\
\hline Gln & 28 \\
\hline Glu & 35 \\
\hline Gly & 53 \\
\hline His & 12 \\
\hline Ile & 51 \\
\hline Leu & 51 \\
\hline Lys & 57 \\
\hline Met & 19 \\
\hline Phe & 39 \\
\hline Pro & 18 \\
\hline Ser & 57 \\
\hline Thr & 55 \\
\hline Trp & 7 \\
\hline Tyr & 47 \\
\hline Val & 37 \\
\hline
\end{tabular}

phosphorylation sites of protein [10]. Further SignalP-4.1 server was used for denoting the presence and location of signal peptide cleavage sites in given sequences [11]. The 3D structure of corresponding protein sequence was predicted with the help of homology modeling tool Modeller 9.11 and was validated by using PROCHECK which gives the result in the form of Ramachandran Plot. Active site of the predicted structure was predicted by using CASTp. Computer aided ligand docking was carried out using the automated Autodock 4.3 program. Also the potential herbal and synthetic ligands were selected out based on their chemical complementarity and stearic fit within the binding site of the Chondroitin AC Lyase. This technique can predict the different bound ligand conformations in absence of the results from conventional techniques [12] [Table 2]. 


\section{Results and Discussion}

Primary analysis reveals that Columnaris enzyme Chondroitin AC Lyase ( $\mathrm{pI}=8.55)$ is basic in character. The computed isoelectric point (pI) will be useful for developing buffer system for purification by isoelectric focusing method. The computed protein concentration and extinction coefficients help in the quantitative study of protein-protein and proteinligand interactions in solution. On the basis of instability index Expasy's ProtParam classifies Chondroitin AC Lyase (31.46) as stable protein $\backslash$ enzyme. The aliphatic index refers to the relative volume of a protein that is occupied by aliphatic side chains and contributes to the increased thermostability of protein. Moderate aliphatic index (72.42) indicates that its structure is somewhat stable and is stable structure over a moderate temperature range. The GRAVY index of protein $(-0.535)$ revealed that it can interact with water effectively. Protein phosphorylation sites determination is usually the initial step in the explanation of a regulation mechanism and its description is the prerequisite for the functional analysis of phosphorylation by mutational analysis. Phosphorylation sites are another important characteristic feature which tells about the serine, threonine, and tyrosine residues in eukaryotic proteins. The predicted phosphorylation sites by NETPHOS of Choindroitin AC Lyase protein is located in (Figure $1 \& 2$ ) Cleavage sites are specific peptide sequences, or more often, peptide motifs where site-specific proteases cleave or cut the protein. Figure 3 illustrates the signal peptide cleavage sites for the protein Chondroitin AC Lyase.

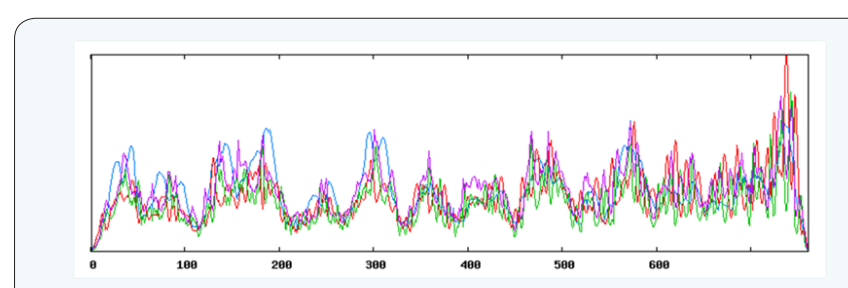

Figure 1: Results of SOPMA analysis.
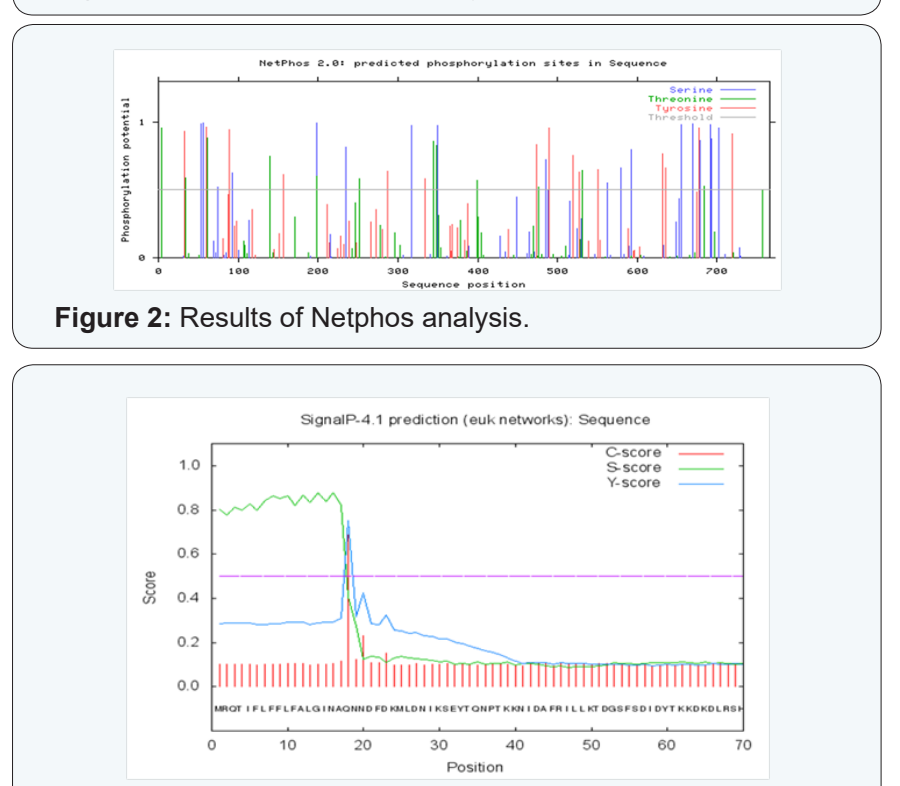

Figure 3: Results of SignalP analysis.
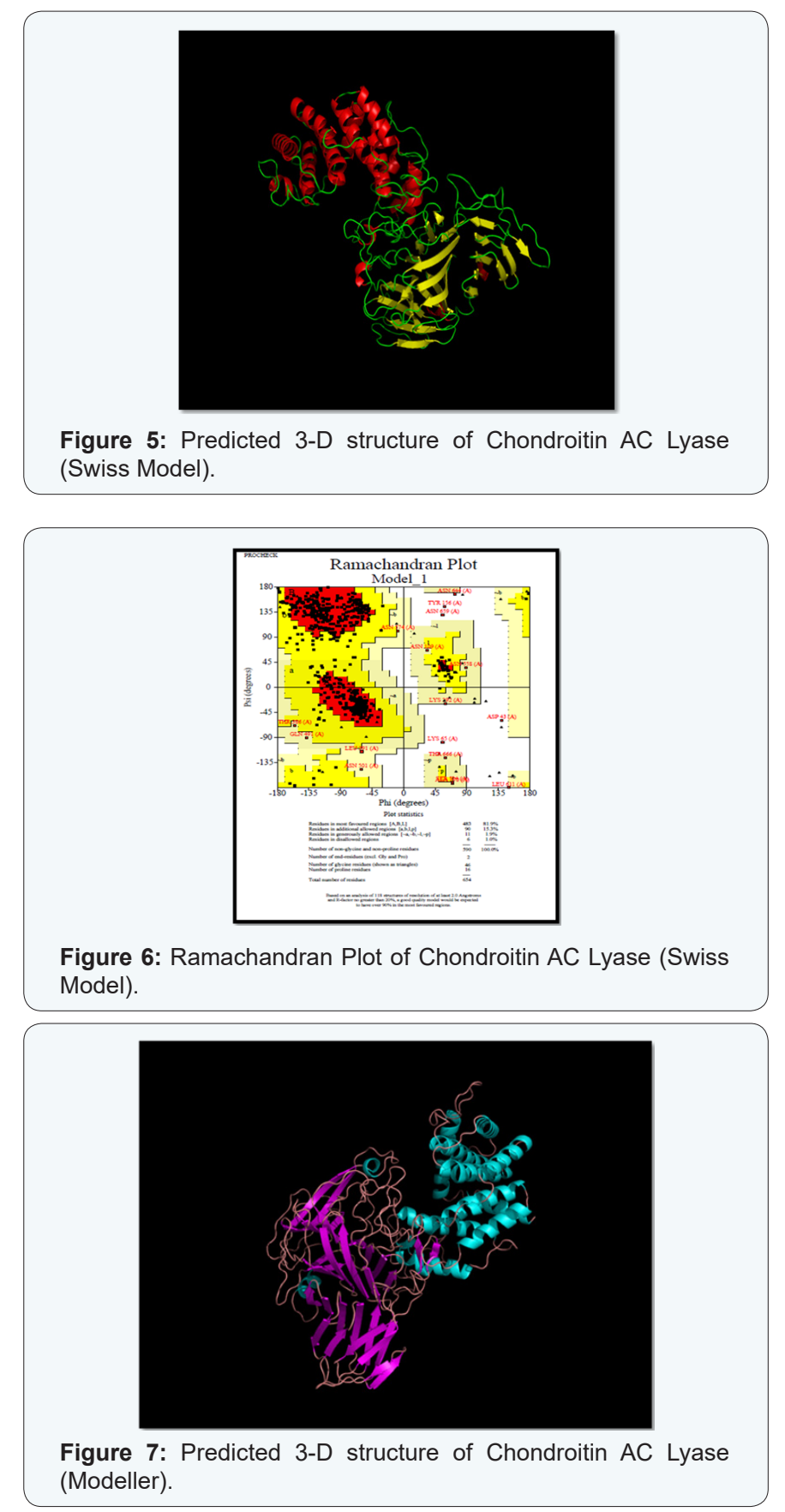

3D structure and functional proteomics is nowhere in existence without the knowledge of protein structure at its tertiary level. Hence exploration of 3D structure of targeted protein Chondroitin AC Lyase, being done by using approach of Homology Modelling. The Swiss model software generated the 3D model structures of query proteins Chondroitin AC Lyase (Figure 5). Ramachandran plot analysis (by PROCHECK) of the enzyme showed $81.9 \%$ in favoured regions (Figure 6). Modeller 9.11 generated the 3D models of Chondroitin AC Lyase based on template proteins $(1 \mathrm{cb} 8,1 \mathrm{f} 1 \mathrm{~s}, 1 \mathrm{hn} 0,1 \mathrm{j} 0 \mathrm{~m}, 1 \mathrm{n} 7 \mathrm{o}, 1 \mathrm{rwh})$ by basic modelling (Figure 7). The Ramachandran plot analysis (by PROCHECK) of this model structure showed that of the residues $88.0 \%$ and $11.8 \%$ are in favoured and additional allowed regions 
respectively (Figure 8). The structure produced by Modeller shows more residues in favoured region so we have taken Modeller Chondroitin AC Lyase structure for docking studies. As it is well accepted that Modeller and Swiss model software develops more accurate and authentic protein structure model which were further validated by PROCHECK, for these reasons, we selected these softwares for our query sequence. Of course 3D structure is pre-requisite for further advance approaches virtual screening or docking studies.

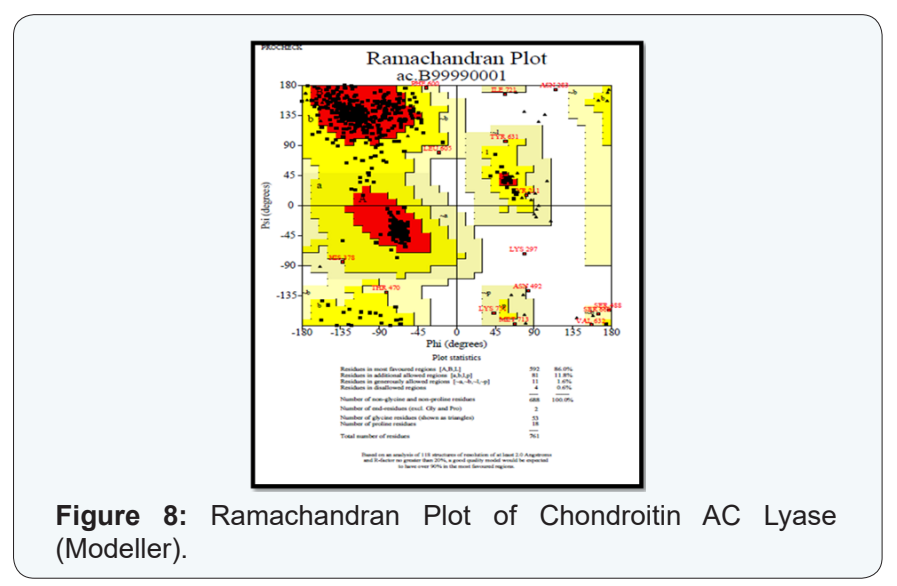

A result conclusive about the virtual screening of phytochemicals for Chondroitin AC Lyase reflects that NIMBOLIDE is best suited ligand (Table 3). Prediction of functional sites by CASTP was effective for docking of phytochemicals with Chondroitin AC Lyase which shows the interaction of Chondroitin AC Lyase domains with NIMBOLIDE (Figure 4). Binding energy calculation results of drug receptor interaction, with different herbal compounds, are given in (Table 3). This efficacy and suitability of ligand was determined on the basis of binding energy calculations. Hence it suggests that the mentioned phytochemicals can be used as ligand for advance drug design after in vitro and in vivo validation.

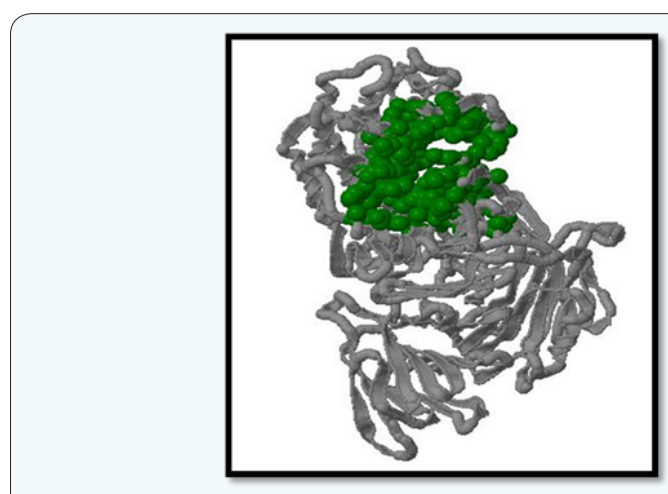

Figure 4: Results of CastP analysis.
Table 3: Docking Studies.

\begin{tabular}{|c|c|c|c|}
\hline Protein & $\begin{array}{c}\text { Ligands } \\
\text { (Phytochemicals/ } \\
\text { Drug) }\end{array}$ & $\begin{array}{l}\text { Binding } \\
\text { Energy }\end{array}$ & $\begin{array}{l}\text { Reference } \\
\text { RMSD }\end{array}$ \\
\hline $\begin{array}{l}\text { Chondroitin AC } \\
\text { Lyase }\end{array}$ & Eugenol & -5.49 & 47.32 \\
\hline $\begin{array}{c}\text { Chondroitin AC } \\
\text { Lyase }\end{array}$ & Caryophyllene & -3.70 & 45.34 \\
\hline $\begin{array}{c}\text { Chondroitin AC } \\
\text { Lyase }\end{array}$ & Linoleic Acid & -3.23 & 49.30 \\
\hline $\begin{array}{c}\text { Chondroitin AC } \\
\text { Lyase }\end{array}$ & Azadiradione & +130.69 & 48.99 \\
\hline $\begin{array}{l}\text { Chondroitin AC } \\
\text { Lyase }\end{array}$ & Nimbolide & -10.55 & 51.24 \\
\hline $\begin{array}{c}\text { Chondroitin AC } \\
\text { Lyase }\end{array}$ & Dehydrosalannol & +232.67 & 44.29 \\
\hline $\begin{array}{c}\text { Chondroitin AC } \\
\text { Lyase }\end{array}$ & Salannin & +233.01 & 44.56 \\
\hline $\begin{array}{c}\text { Chondroitin AC } \\
\text { Lyase }\end{array}$ & Ascorbic Acid & -4.80 & 47.16 \\
\hline $\begin{array}{c}\text { Chondroitin AC } \\
\text { Lyase }\end{array}$ & Coumarins & -4.03 & 48.05 \\
\hline $\begin{array}{c}\text { Chondroitin AC } \\
\text { Lyase }\end{array}$ & $\begin{array}{l}\text { Oxytetracycline } \\
\text { (Drug) }\end{array}$ & +65.15 & 46.93 \\
\hline
\end{tabular}

\section{Conclusion}

Current studies reveals that Nimbolide is showing best interaction among virtually screened ligands resulting into significant docking score and also form hydrogen bond and several hydrophobic interactions between active site of Chondroitin AC Lyase enzyme. .n the basis of significant importance at the level of functionality as well as their involvement in progression of Columnaris disease, we developed a 3D structure of Chondroitin AC Lyase protein by In-silico modeling approach. In-silico characterization and 3-D structure prediction along with comparative docking studies reveals that Nimbolide can be used as a better herbal ligand in prophylactic measures or as a drug against Columnaris disease by targeting Chondroitin AC Lyase protein [Figure 9]. 


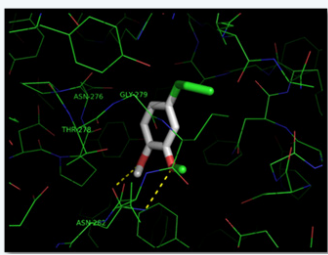

(a)

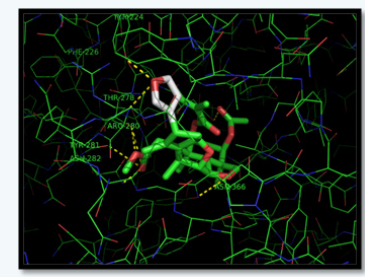

(f)

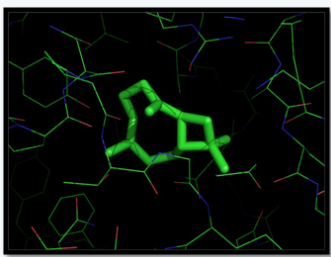

(b)

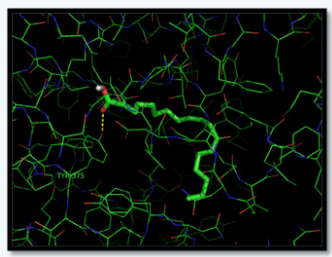

(c)

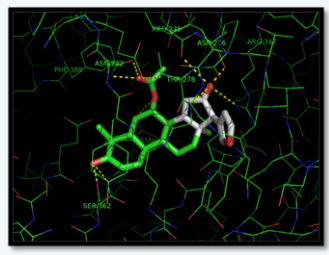

(d)

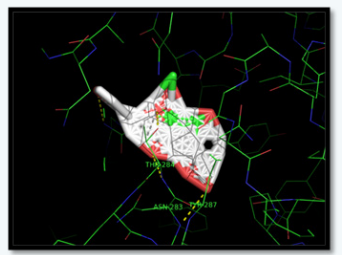

(e)

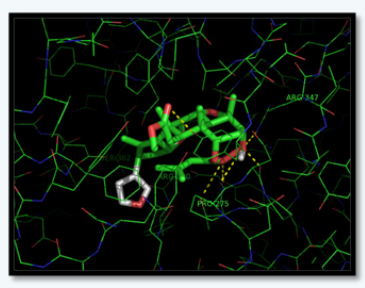

(g)

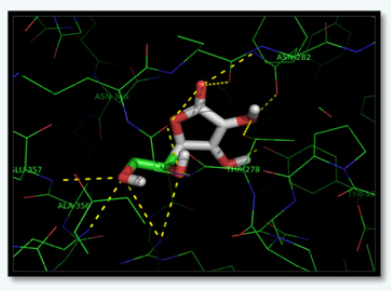

(h)

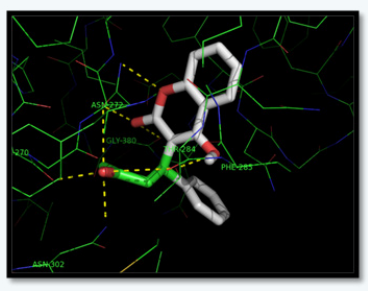

(i)

Figure 9: Protein Ligand interaction. The docked complexes are (a) Euginol (b) Caryophyllene (c) Linoleic Acid (d) Azadiradione (e) Nimbolide (f) Salannin (g) Dehydrosalannol (h) Ascorbic Acid (i) Coumarins.

\section{Ethical Statement}

Complete study is based on computational approaches without using any animal model. Hence, ethical clearance is not required.

\section{References}

1. Leadbetter ER (1974) The genus Flexibacter. Bergey's Manual of Determinative Bacteriology 8: 105-107.

2. McCarthy DM (1975) Columnaris disease. J Inst Fish Mgmt 6(2): 44-47.

3. Amend D (1982) FColumnaris (Flexi bacter columnaris) disease of freshwater fishes and a brief review of other flexibacterial diseases of fish. In: Anderson DP, Dorson M, Dubourget P (Eds.), Antigens of fish pathogens. Symposium international de Talloires, Collection Fondation Marcel Merieux, Lyon, pp. 139-151.

4. Holt RA, Sanders JE, Zinn JL, Fryer JL, Pilcher KS (1975) Relation of water temperature to Flexibactercolumnwi infection in steelhead trout (Salmo gairdneri), coho (Oncorhynchus kisutch) and chinook (0. tshawytscha) salmon. J Fish Res Board Can 32(9): 1553-1559.

5. Snieszko SF (1981) Bacterial gill disease of freshwater fishes. US Fish \& Wildlife Publications, USA, pp. 147.
6. Pereira MJ (2012) Characterization of chondroitin AC lyase in Flavobacterium columnare. Dissertations and Master's Theses, The University of Rhode Island, USA.

7. The UniProt consortium (2012) Reorganizing the protein space at the Universal Protein Resource (UniProt). Nucleic Acids Res 40: 71-75.

8. Gasteiger E, Hoogland C, Gattiker A, Duvaud S, Wilkins MR, et al. (2005) Protein identification and analysis tools on the ExPASy Server. The Proteomics Protocols Handbook, Humana Press, pp. 571-607.

9. Geourjon C, Deléage G (1995) SOPMA: significant improvements in protein secondary structure prediction by consensus prediction from multiple alignments. Comput Appl Biosci 11(6): 681-684.

10. Blom N, Gammeltoft S, Brunak S (1999) Sequence and structure based prediction of eukaryotic protein phosphorylation sites. Journal of Molecular Biology 294(5): 1351-1362.

11. Petersen TN, Brunak S, Heijne G, Nielsen H (2011) Signal P 4.0: discriminating signal peptides from transmembrane regions. Nature Methods 8(10): 785-786.

12. Alaa El Din A Gawad (2012) In Silico Docking Analysis of Rat $\gamma$-Crystalline Surfaces. Journal of Computations \& Modelling 2(3): 3166.

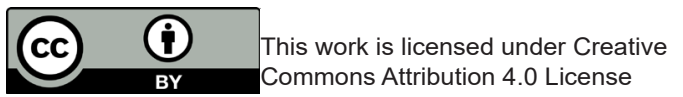

\begin{tabular}{l} 
Your next submission with Juniper Publishers \\
will reach you the below assets \\
- Quality Editorial service \\
- Swift Peer Review \\
- Reprints availability \\
- E-prints Service \\
- Manuscript Podcast for convenient understanding \\
- Global attainment for your research \\
- Manuscript accessibility in different formats \\
( Pdf, E-pub, Full Text, Audio) \\
- Unceasing customer service \\
Track the below URL for one-step submission \\
https://juniperpublishers.com/online-submission.php \\
\hline
\end{tabular}

